Edunomika - Vol. 01, No. 01 (Pebruari 2017)

\title{
PENINGKATAN PRESTASI BELAJAR MELALUI MODEL PEMBELAJARAN YANG TEPAT PADA SEKOLAH DASAR SAMPAI PERGURUAN TINGGI
}

\author{
Sri Lahir ${ }^{1)}$, Muhammad Hasan Ma'ruf ${ }^{2)}$, Muhammad Tho'in ${ }^{3)}$ \\ 1) Alumni Program Doktor Manajemen Pendidikan, Universitas Negeri Semarang \\ 2) Sekolah Tinggi Ilmu Ekonomi AAS Surakarta, Jawa Tengah \\ 3) Sekolah Tinggi Ilmu Ekonomi AAS Surakarta \\ Email:srilahir@gmail.com
}

\begin{abstract}
Abstrak: Banyak metode atau model pembelajaran yang dapat dilakukan oleh guru atau dosen dalam rangka meningkatkan prestasi belajar peserta didiknya. Tujuan dari penelitian ini adalah untuk melihat metode yang digunakan oleh guru atau dosen dalam meningkatkan prestasi belajar pasa sekolah dasar dan menengah (guru) sampai perguruan tinggi (dosen) . hasil penelitian menunjukkan ada lima metode atau model pembelajaran yang sering digunakan oleh guru atau dosen kepada peserta didiknya, yaitu metode Numbered Heads Together (NHT), metode Cooperative Script, metode Student Teams Achievement Divisions (STAD), model pembelajaran jigsaw, dan metode role playing. Dengan penerapan model yang sesuai dan tepat akan dapat meningkatkan prestasi belajar siswa atau mahasiswa dalam belajarnya.
\end{abstract}

Kata Kunci: prestasi belajar, model pembelajaran, sekolah dasar sampai perguruan tinggi

\begin{abstract}
Many methods or learning models that can be done by teachers or lecturers in order to improve student achievement learners. The purpose of this study is to see the methods used by teachers or lecturers in improving learning achievement pasa elementary and secondary (teachers) to college (lecturer). the results of the study indicate that there are five methods or models of learning that are often used by teachers or lecturers to their students, the method of Numbered Heads Together (NHT), Cooperative Script method, Student Teams Achievement Divisions (STAD) method, jigsaw learning model, and role playing method. With the application of appropriate and appropriate model will be able to improve student achievement or student in learning.
\end{abstract}

Keywords: learning achievement, learning model, elementary school until college

\section{PENDAHULUAN}

Bangsa Indonesia adalah bangsa besar yang memiliki berbagai sumber daya alam. Tetapi sumber daya alam yang melimpah inilah yang disinyalir justru menjadi faktor rendahnya tingkat kedisiplinan dan kerja keras rakyat bangsa ini. Sebagaimana pendapat yang dikemukakan oleh Anis Baswedan (2014), beliau berpendapat bahwasannya kekayaan bangsa Indonesia bukan pada gas, tambang, laut, atau bahkan hutannya. Tetapi kekayaan bangsa Indonesia terletak pada manusianya. Ditegaskan oleh beliau, "kita selama ini lebih tahu mengenai ekspor impor daripada sekolah, guru, kesehatan," kata Anies saat berbicara di 
seminar Uji Publik Capres 2014: Mencari Pemimpin Muda Berkualitas yang diadakan The Habibie Center, di Jakarta, Rabu (26/3/2014). https://nasional.kompas.com/read/ 2014/03/26/1149102/Anies.Kekayaan. Indonesia.Ada.pada.Sumber.Daya.Manusia.

Kekayaan manusia disini selain kesehatan faktor dominan dalam memenangkan pasar

global adalah pendidikan. Karena dimanapun negara-negara maju seperti Finlandia, Korea Selatan, Jepang, Hongkong, Singapura dan beberapa negara lainnya, tidak dapat dipungkiri di negara mereka memiliki sistem pendidikan yang baik dan bermutu dari tingkat dasar sampai perguruan tingginya. Kemudian jika diamati kesuksesan dalam sistem pendidikannya karena tenaga pengajar, baik guru maupun dosennya menggunakan metode atau model pembelajaran yang sesuai dengan kultur serta kemampuan peserta didiknya. Mereka tidak memaksakan diri dengan menggunakan suatu metode atau model yang monoton, karena memahami.

Metode atau model pembelajaran yang tepat sesuai dengan kondisi peserta didiknya, akan menjadikan peserta didik (siswa maupun mahasiswa) menjadi lebih mudah menerima materi yang disampaikan oleh guru maupun dosen. Jika ada kesulitan-kesulitan yang dialami peserta didik, seorang guru dan dosen harus mampu memberikan solusi semaksimal mungkin agar kesulitan-kesulitan itu semakin lama dapat teratasi, sehingga prestasi belajar mereka akan semakin meningkat sesuai dengan yang diharapkan bersama oleh semua pihak dan pada akhirnya semua pihak akan terpuaskan.

Model berasal dari Bahasa Yunani "Methodos" yang berarti cara atau jalan yang ditempuh. Fungsi model berarti sebagai alat untuk mencapai tujuan. Pengetahuan tentang model-model sangat diperlukan oleh para pendidik, karena berhasil tidaknya siswa belajar sangat bergantung kepada tepat tidaknya model mengajar yang yang digunakan oleh guru. Model mengajar mampu membangkitkan motivasi, minat atau gairah belajar siswa bahkan mampu meningkatkan hasil belajar siswa.

Menurut Kamus Besar Bahasa Indonesia (2008:740) model adalah cara teratur yang digunakan untuk melaksanakan suatu pekerjaan agar tercapai sesuai dengan yang dikehendaki. Menurut Sudjana dalam Adang Heriawan dkk (2012:73) model mengajar adalah cara yang dipergunakan guru dalam mengadakan hubungannya dengan siswa pada saat berlangsungnya pengajaran, peranan model mengajar sebagai alat untuk menciptakan proses mengajar dan belajar.

Dari beberapa pendapat yang dikemukakan oleh para ahli di atas, dapat disimpulkan bahwa model adalah cara yang digunakan oleh seseorang dalam melaksanakan suatu pekerjaan. Dalam hal ini adalah cara-cara yang dilakukan oleh guru atau dosen dan peserta didik dalam hal ini adalah siswa maupun mahasiswa dalam melaksanakan kegiatan pembelajaran sesuai dengan tujuan yang diharapkan secara bersama-sama yaitu semakin adanya peningkatan prestasi belajar.

\section{KAJIAN TEORI}

\section{Hasil Belajar}

Menurut pendapat yang dikemukakan oleh R. Gagne dimana dia memberikan dua definisi belajar, yaitu belajar adalah suatu proses untuk memperoleh motivasi dalam pengetahuan, 
keterampilan, kebiasaan, dan tingkah laku. Belajar adalah penguasaan pengetahuan atau keterampilan yang diperoleh dari instruksi (Slameto, 2000: 78). Sedangkan pendapat yang dikemukakan oleh Skinner bahwa belajar merupakan hubungan antara stimulus dan respon yang tercipta melalui proses tingkah laku (Dimyati dan Mudjiono, 2006: 93). Hal lain dikemukakan oleh Sutikno (2010:35), dimana beliau mengemukakan definisi belajar, belajar merupakan suatu proses usaha yang dilakukan oleh seseorang untuk memperoleh suatu perubahan yang baru sebagai hasil pengalamannya sendiri dalam interaksi dengan lingkungannya.

Dari pengertian-pengertian yang dikemukakan oleh para ahli di atas, maka dapat disimpulkan bahwasanya yang dimaksud dengan belajar adalah perubahan serta peningkatan kualitas dan kuantitas tingkah laku yang ada pada seseorang di berbagai bidang yang terjadi akibat adanya suatu interaksi yang terjadi terus menerus dengan lingkungan yang ia tempati.

Hasil belajar siswa yang dikemukakan oleh Winkel (2004:82), hasil belajar siswa adalah suatu keberhasilan yang dicapai oleh para siswa, yakni prestasi belajar siswa di sekolah yang mewujudkan dalam bentuk angka. Dimana hasil belajar adalah pola-pola perbuatan, nilai-nilai, pengertian-pengertian, sikap-sikap, apresiasi dan keterampilan-keterampilan (Suprijono, 2011:5). Hasil belajar adalah hasil yang dicapai dalam bentuk angka atau skor setelah tes hasil belajar pada setiap akhir pembelajaran (Dimyati dan Mujiono, 2006:24).

Dari berbagai definisi di atas, dapat ditarik kesimpulan bahwasanya hasil belajar merupakan suatu prestasi belajar yang dicapai oleh siswa dalam proses kegiatan belajar mengajar dengan membawa suatu perubahan serta adanya suatu pembentukan tingkah laku atau sikap perilaku seseorang. Untuk dapat dikatakan suatu proses belajar berhasil, setiap guru maupun dosen memiliki pandangan yang berbeda-beda sejalan dengan ilmu pengetahuannya. Namun untuk menyamakan sebuah persepsi, lebih baik kita senantiasa berpedoman kepada kurikulum yang berlaku yang telah disempurnakan semakin lebih baik, antara lain bahwa suatu proses belajar mengajar tentang suatu bahan pembelajaran akan dinyatakan berhasil dalam pelaksanaannya apabila tujuan pembelajaran khususnya yang dilakukan dapat dicapai sesuai dengan harapan.

Untuk mengetahui tercapai atau tidaknya tujuan pembelajaran khusus, guru maupun dosen perlu mengadakan suatu tes formatif pada setiap menyajikan suatu bahasan atau materi kepada siswanya atau mahasiswanya. Penilaian formatif yang dilakukan untuk mengetahui sejauh mana siswa maupun mahasiswa telah menguasai tujuan pembelajaran khusus yang akan dicapai bersama. Fungsi dilakukan suatu penelitian ini yaitu untuk memberikan suatu umpan balik pada guru maupun dosen dalam rangka memperbaiki suatu proses pembelajaran dari dasar sampai perguruan tinggi dan melaksanakan program remedial bagi anak didiknya yang belum berhasil dalam pencapaian tujuan pembelajaran dengan bukti adanya peningkatan prestasi belajar. Oleh karenanya, suatu proses belajar mengajar yang telah dilaksanakan dinyatakan berhasil apabila hasil yang dicapai berhasil memenuhi tujuan pembelajaran khusus dari bahan maupun materi yang disampaikan tersebut.

Hasil belajar yang dicapai oleh peserta didik, baik siswa pada sekolah dasar dan sekolah menengah maupun mahasiswa di perguruan tinggi merupakan salah satu ukuran terhadap 
penguasaan suatu materi pelajaran yang telah disampaikan oleh guru maupun dosen. Peran guru dan dosen dalam menyampaikan materi pelajaran dapat mempengaruhi hasil belajar yang dicapai oleh peserta didiknya. Faktor-faktor yang dapat mempengaruhi dari hasil belajar peserta didik penting sekali untuk diketahui oleh dosen dan guru, artinya dalam rangka membantu siswa dan mahasiswa mencapai hasil belajar secara maksimal. Hasil belajar yang telah dicapai oleh peserta didik dipengaruhi oleh dua faktor, faktor tersebut ada yang bersifat mendorong dan ada faktor yang bersifat menghambat, demikian pula dalam proses belajar yang dilakukan antara pendidik dan peserta didik. Faktor yang mempengaruhi dari hasil belajar peserta didik terdiri atas: faktor dari dalam diri siswa itu sendiri dan faktor dari luar siswa. Ahmadi (1998:72) berpendapat bahwasanya untuk mencapai suatu peningkatan prestasi belajar siswa sebagaimana yang diharapkan, maka perlu diperhatikan beberapa faktor yang mempengaruhinya antara lain faktor intern dan faktor ekstern.

\section{Model Pembelajaran}

Metode atau model pembelajaran yang tepat sesuai dengan kondisi peserta didiknya, akan menjadikan peserta didik (siswa maupun mahasiswa) menjadi lebih mudah menerima materi yang disampaikan oleh guru maupun dosen. Jika ada kesulitan-kesulitan yang dialami peserta didik, seorang guru dan dosen harus mampu memberikan solusi semaksimal mungkin agar kesulitan-kesulitan itu semakin lama dapat teratasi, sehingga prestasi belajar mereka akan semakin meningkat sesuai dengan yang diharapkan bersama oleh semua pihak dan pada akhirnya semua pihak akan terpuaskan.

Model berasal dari Bahasa Yunani "Methodos" yang berarti cara atau jalan yang ditempuh. Fungsi model berarti sebagai alat untuk mencapai tujuan. Pengetahuan tentang model-model sangat diperlukan oleh para pendidik, karena berhasil tidaknya siswa belajar sangat bergantung kepada tepat tidaknya model mengajar yang yang digunakan oleh guru. Modelmengajar mampu membangkitkan motivasi, minat atau gairah belajar siswa bahkan mampu meningkatkan hasil belajar siswa.

Menurut Kamus Besar Bahasa Indonesia (2008: 740) model adalah cara teratur yang digunakan untuk melaksanakan suatu pekerjaan agar tercapai sesuai dengan yang dikehendaki. Menurut Sudjana dalam Adang Heriawan dkk (2012: 73) model mengajar adalah cara yang dipergunakan guru dalam mengadakan hubungannya dengan siswa pada saat berlangsungnya pengajaran, peranan model mengajar sebagai alat untuk menciptakan proses mengajar dan belajar.

Metode pembelajaran didefinisikan sebagai cara yang digunakan guru, yang dalam menjalankan fungsinya merupakan alat untuk mencapai tujuan pembelajaran (Uno, 2008: 2). Hal tersebut juga sejalan dengan pendapat Slavin (2010: 9) bahwa metode pembelajaran sebagai elemen utama dalam pola pengaturan kelas dan digunakan secara ekstensif dalam tiap subjek yang dapat dikonsepkan pada tingkat kelas. 


\section{METODE}

Jenis penelitian ini adalah penelitian diskriptif kualitatif, metode penelitian yang dilakukan disesuaikan dengan konteks penelitian. Dalam penelitian yang berjudul peningkatan prestasi belajar melalui model pembelajaran yang tepat pada sekolah dasar sampai perguruan tinggi menggunakan studi pustaka. Dimana studi pustaka tersebut diperoleh dari sumbersumber yang relevan dengan topik penelitian ini seperti buku, jurnal, dan lain-lain.

\section{PEMBAHASAN}

Metode pembelajaran yang ada sangat banyak sekali, namun dalam penelitian ini hanya akan membahas serta mengulas 5 (lima) model atau metode pembelajaran yang sering digunakan oleh pendidik kepada peserta didik. kelima model pembelajaran tersebut yang akan dijelaskan sebagai berikut:

\section{Numbered Heads Together (NHT)}

Metode Numbered Heads Together (NHT) merupakan salah satu tipe dari pembelajaran koperatif dengan sintaks: pengarahan, buat kelompok heterogen dan tiap siswa memiliki nomor tertentu, berikan persoalan materi bahan ajar (untuk tiap kelompok sama tapi untuk tiap siswa tidak sama sesuai dengan nomor siswa, tiasp siswa dengan nomor sama mendapat tugas yang sama) kemudian bekerja kelompok, presentasi kelompok dengan nomnor siswa yang sama sesuai tugas masing-masing sehingga terjadi diskusi kelas, kuis individual dan buat skor perkembangan tiap siswa, umumkan hasil kuis dan beri reward.

Langkah-langkah metode Numbered Heads Together (NHT) adalah:

a. Siswa dibagi dalam kelompok-kelompok belajar, setiap siswa dalam setiap kelompok mendapat nomor.

b. Guru atau dosen memberikan tugas dan masing-masing kelompok yang telah ditentukan mengerjakannya tugasnya tersebut.

c. Kelompok melakukan diskusi mengenai jawaban yang benar serta memastikan bahwa setiap anggota kelompok dapat mengerjakannya dan atau mengetahui jawabannya.

d. Guru atau dosen memanggil salah satu nomor siswa/mahasiswa dengan nomor yang dipanggil tersebut kemudian melaporkan hasil kerjasama yang telah mereka kerjakan.

e. Adanya tanggapan dari teman yang lain, kemudian guru atau dosen menunjuk atau melakukan penunjukkan nomor yang lain.

f. Membuat kesimpulan dari pelaksanaan pembelajaran dengan menggunakan metode Numbered Heads Together (NHT).

\section{Metode Cooperative Script}

Metode Cooperative Script merupakan metode belajar dimana peserta didik bekerja secara berpasangan serta bergantian secara lisan mengikhtisarkan, bagian-bagian dari bahan atau materi yang dipelajari (Danserau cs., 1985).

Langkah-langkah metode Cooperative Script adalah:

a. Guru atau dosen membagi peserta didik (siswa/mahasiswa) untuk berpasangan. 
b. Guru atau dosen membagikan materi tiap siswa/mahasiswa untuk dibaca dan membuat sebuah ringkasan dari materi tersebut.

c. Guru atau dosen dan peserta didik menetapkan siapa yang pertama akan berperan sebagai pembicara serta menetapkan pula siapa yang berperan sebagai pendengar.

d. Pembicara membacakan hasil dari ringkasannya selengkap mungkin, dengan memasukkan ide-ide pokok dalam ringkasannya. Sementara pendengar menyimak, melakukan koreksi, serta menunjukkan ide-ide pokok yang kurang lengkap, kemudian membantu mengingat atau menghafal ide-ide pokok dengan menghubungkan materi sebelumnya dengan materi lainnya.

e. Melakukan pertukaran peran, semula sebagai pembicara ditukar menjadi pendengar dan semula pendengar menjadi pembicara.

f. Membuat kesimpulan secara bersama-sama antara peserta didik dengan guru atau dosen.

\section{Metode Student Teams Achievement Divisions (STAD)}

Metode Student Teams Achievement Divisions (STAD) merupakan salah satu model pembelajaran koperatif dengan sintaks: pengarahan, buat kelompok heterogen (4-5 orang), diskusikan bahan belajar-LKS-modul secara kolabratif, sajian presentasi kelompok sehingga terjadi diskusi kelas, kuis individual dan buat skor perkembangan tiap siswa atau kelompok, umumkan rekor tim dan individual dan berikan reward. Kooperatif Tim Siswa Kelompok Prestasi (Slavin, 1995)

Langkah-langkah metode Student Teams Achievement Divisions (STAD) adalah:

a. Membentuk kelompok-kelompok, dimana setiap kelompok anggotanya 4 orang secara heterogen (campuran menurut prestasi, jenis kelamin, suku, dan lain sebagainya).

b. Guru atau dosen menyajikan pelajaran.

c. Guru atau dosen memberi tugas kepada kelompok siswa atau mahasiswa untuk dikerjakan oleh anggota-anggota kelompok tersebut. Dimana anggota yang sudah mengerti atau paham terhadap materi tersebut dapat menjelaskan pada anggota lainnya sampai semua anggota yang ada dalam kelompok itu memahaminya.

d. Guru atau dosen memberi kuis atau suatu pertanyaan kepada seluruh peserta didik (siswa atau mahasiswa). Dimana siswa atau mahasiswa tersebut pada saat menjawab kuis tidak boleh saling membantu satu sama lain.

e. Memberi evaluasi atas segala proses pembelajaran yang telah terlaksana.

f. Membuat kesimpulan.

\section{Jigsaw}

Model pembelajaran jigsaw ini termasuk jenis pembelajaran koperatif dengan sintaks seperti: pengarahan, informasi bahan ajar, buat kelompok heterogen, berikan bahan ajar (LKS) yang terdiri dari beberapa bagian sesuai dengan banyak siswa dalam kelompok, tiap anggota kelompok bertugas membahasa bagian tertentu, kemudian setiap kelompok bahan belajar sama, buat kelompok ahli sesuai bagian bahan ajar yang sama sehingga terjadi kerja 
sama dan diskusi, kembali ke kelompok asalnya, pelaksnaa tutorial pada kelompok asal oleh anggota kelompok ahli, penyimpulan dan evaluasi, refleksi. Kooperatif Model Tim Ahli (Aronson, Blaney, Stephen, Sikes, And Snapp, 1978)

Langkah-langkah metode Jigsaw adalah:

a. Perserta didik dikelompokkan ke dalam beberapa anggota tim.

b. Dimana setiap orang dalam tim tersebut diberi bagian materi yang berbeda.

c. Setiap orang atau anggota dalam tim diberi bagian materi yang ditugaskan.

d. Anggota dari tim yang berbeda yang telah mempelajari bagian atau sub bab yang sama bertemu dalam kelompok baru (kelompok ahli) untuk mendiskusikan sub bab mereka yang sudah memahami bagian atau sub bab tersebut.

e. Setelah selesai melakukan diskusi sebagai tim ahli tiap anggota kembali ke kelompok semula atau masing-masing dan bergantian mengajar teman satu tim mereka tentang sub bab yang mereka kuasai dan tiap anggota lainnya mendengarkan dengan penuh keseriusan atau sungguh-sungguh

f. Kemudian setiap tim ahli mempresentasikan hasil diskusi yang sudah dilakukan.

g. Guru atau dosen memberikan evaluasi atas pelaksanaan pembelajaran.

h. Guru atau dosen menutup kegiatan pembelajaran.

\section{Role Playing}

Sintak dari model pembelajaran role playing adalah guru atau dosen menyiapkan sebuah skenario pembelajaran, menunjuk beberapa siswa atau mahasiswa untuk mempelajari skenario tersebut, pembentukan kelompok siswa atau mahasiswa, penyampaian kompetensi, menunjuk peserta didik untuk melakonkan skenario yang telah dipelajari tersebut, kelompok siswam atau mahasiswa membahas peran yang dilakukan oleh pelakon, presentasi hasil kelompok, bimbingan dan refleksi.

Langkah-langkah metode Role Playing adalah:

a. Guru menyusun/menyiapkan skenario yang akan ditampilkan.

b. Guru atau dosen menunjuk beberapa siswa atau mahasiswa untuk mempelajari skenario dalam waktu beberapa hari sebelum dilakukannya kegiatan belajar mengajar.

c. Guru atau dosen membentuk kelompok siswa atau mahasiswa yang anggotanya 5 orang.

d. Guru atau dosen memberikan penjelasan tentang kompetensi yang ingin dicapai.

e. Guru atau dosen memanggil para siswa atau mahasiswa yang sudah ditunjuk untuk melakonkan skenario yang sudah dipersiapkan sebelumnya.

f. Masing-masing siswa atau mahasiswa berada di kelompoknya sambil mengamati skenario yang sedang diperagakan temannya.

g. Setelah semua bagian selesai ditampilkan, masing-masing siswa atau mahasiswa diberikan lembar kerja untuk membahas penampilan masing-masing kelompok.

h. Masing-masing kelompok yang telah ditunjuk menyampaikan hasil kesimpulannya.

i. Guru atau dosen memberikan kesimpulan secara umum.

j. Dilakukan evaluasi.

k. Guru atau dosen menutup kegiatan belajar mengajar. 
Srilahir, dkk / Edunomika Vol. 01 No. 01 (Pebruari 2017)

\section{SIMPULAN}

Berdasarkan pembahasan, bahwasannya sangat banyak metode atau model pembelajaran yang dapat dilakukan oleh guru atau dosen dalam rangka meningkatkan prestasi belajar peserta didiknya. Ada lima metode atau model pembelajaran yang sering digunakan oleh guru atau dosen kepada peserta didiknya, yaitu metode Numbered Heads Together (NHT), metode Cooperative Script, metode Student Teams Achievement Divisions (STAD), model pembelajaran jigsaw, dan metode role playing. Dengan penerapan model yang sesuai dan tepat akan dapat meningkatkan prestasi belajar siswa atau mahasiswa dalam belajarnya.

\section{DAFTAR PUSTAKA}

Adang Heriawan. 2012. Metodologi Pembelajaran Kajian Teoritis Praktis

Ahmadi, Mukhsin. 1990. Strategi Belajar-Mengajar Keterampilan Berbahasa dan Apresiasi Sastra. Malang: YA3

Baswedan, Anis. 2014. Kekayaan Indonesia Ada Pada Sumber Daya Manusianya. di seminar Uji Publik Capres 2014: Mencari Pemimpin Muda Berkualitas yang diadakan The Habibie Center, di Jakarta, Rabu (26/3/2014).

Dansereau Cs. 1985. Cooperative Learning Tipe Cooperative Script

Dimyati dan Mudjiono. 2006. Belajar dan Pembelajaran. Jakarta: Rineka Cipta

Heriawan, Adang, dkk. 2012. Metodologi Pembelajaran Kajian Teoritis Praktis Model, Pendekatan, Strategi, Metode, dan Teknik Pembelajaran. Banten: LP3G.

https://nasional.kompas.com/read/2014/03/26/1149102/Anies.Kekayaan.Indonesia.Ada.pada.S umber.Daya.Manusia. diakses pada tanggal 12 Januari 2017.

Kamus Besar Bahasa Indonesia. 2008. Pengertian Model.

M. Sobry Sutikno, (2009). Belajar dan Pembelajaran, Prospect. Bandung

Slameto. 2000. Belajar dan Faktor-faktor yang mempengaruhinya. Rineka Cipta,Jakarta

Slavin, 1995. Cooperative Learning. Boston: Allya Bacon

Slavin, Robert E. (2005). Cooperative Learning: theory, research and practice (N. Yusron. Terjemahan). London: Allymand Bacon. Buku asli diterbitkan tahun 2005.

B. Uno, Hamzah. 2008. Teori Motivasi dan Pengukurannya, Jakarta: Bumi Aksara

Winkel, W.S. 1996. Psikologi Pengajaran. Jakarta: Grasindo. 